\title{
The Application of Shakespeare's Drama in English Major Teaching from the Perspective of Social Constructivist Model
}

\author{
Luo Zhiyong \\ Department of Foreign Languages, Tianjin University of Commerce Boustead College, Tianjin 300384
}

Keywords: Social constructivism, Shakespeare, drama, English major, Teaching, Application.

\begin{abstract}
Social constructivism teaching model is derived based on constructivism, English teaching is an important part of higher education, with the society for high-quality compound application talent demand increasing, knowledge of English application ability of students has become the focus of attention of the problem of higher education for English majors. Shakespeare is a classic drama in English literature, the English and English in specialized teaching can apply specific teaching situation, realize students' comprehensive learning ability, based on the social constructivist model from the perspective of Shakespeare's in-depth research in the application of English teaching, the teaching present situation analysis, social construction of English majors from the viewpoint of the teaching mode of English major construction, Shakespeare plays in the English teaching mode of the application program, designed to promote the teaching level of English Majors upgrading.
\end{abstract}

\section{Introduction}

Constructivism psychology characteristics of education and learning are closely connected, the application of Constructivism interpretation of the learning process and the cognitive rules embodied in the process of learning, social constructivism learning theory focuses on "what is learning", "how to learn" problem analysis, the learners into specific teaching in the context of learning in the context of teaching content and understanding, through the understanding of the learning process, the learning content and in-depth knowledge and teaching situation, collaborative learning, learning process and conversational meaning construction as the main factors of teaching, English majors attach importance to in-depth understanding of the English language and culture in order to understand and grasp the basis for realization of language in different contexts and different emotional expression of application, realization Students transfer from English major knowledge to English skills, thus promoting the teaching goal of English major in higher education, and helping to promote students' professional and personal development. The application of Shakespeare drama for English teaching, fit the social constructivism teaching concept teaching mode from the perspective of students, build new application platform for English learning, contribute to the realization of students' English learning ability and the expression ability, to explore its application way for the effective implementation of social constructivism mode in the teaching of English majors[1].

\section{Teaching situation of English Majors}

Although universities have realized English professional knowledge application is important for the professional development of students, many colleges and universities also carry out various forms of teaching practice to enhance the learning ability and the ability of students, but the teaching effect has little effect, many college students through professional grade six or grade eight examination, oral English is used there will be no pure accent or disorderly pause and other issues, the main problem is the teaching of English Majors in the teaching idea and teaching method is 
relatively lagging behind, students learn in a passive state in the learning process, cramming teaching content to accept the transfer of teachers, students' subjective initiative is inhibited. At the same time, in order to ensure that students can successfully carry out various grades of examination, teachers attach importance to students' knowledge accumulation and examination ability, while students' professional knowledge application ability has been neglected. Many teachers pay more attention to English teaching, but ignore the culture of English and American literature transfer knowledge to students, language and culture is the soul of language, always only on its forms of learning, and the lack of understanding of its connotation and soul, will lead the students can not integrated into the real context of language application, limited students' English comprehensive ability[2].

English major students experience oriented education middle school stage, and in the learning process also reflects the obvious characteristics of the learning oriented education for teachers, classroom teaching and teaching contents have strong psychological dependence, to carry out learning activities according to the teacher's teaching plan, but the lack of independent learning and inquiry consciousness, from the Perspective of knowledge more the narrow, many students have awareness of autonomous learning, also uses a lot of grammar, vocabulary memory and English exercises exercises, attention through various forms of exam, but ignore their own understanding of the English language and culture, many students are still closed by the way to learn English, neglect their own master in English language skills, lack of correct learning concept guidance, naturally difficult to form effective English learning for Therefore, it is difficult for students to improve their English learning ability and application ability[3].

\section{The construction of English major teaching model from the perspective of Social Constructivism}

The implementation of social constructivism theory in the teaching of the teaching situation, teaching activities, teaching process and teaching objectives and content, the main role and deepen the students in the teaching process, the innovation of teaching content according to the needs of the students' learning settings, so that students can learn in the teaching activity to self centered, center of learning activities, the language teaching mode into the language learning, so that students can enhance the ability of autonomous learning, initiative and application of teaching activities to mobilize the students to actively participate in teaching activities. English teaching can make the students' learning mode has become the interaction process between teachers and students, enhance the ability of the formation process of English in practice, so teachers need to be teaching activities as the application of Constructivism mode[4].

English drama is an art English language expression way, application of English drama to carry out professional English teaching activities, the real language environment in the drama into the classroom teaching, practice teaching activities to mobilize the classroom atmosphere to reduce students' professional learning pressure, stimulate students' interest in learning, students can have more English expression self confidence, help to promote the learning efficiency of students, students in the practice activities to promote their English comprehensive application ability. At the same time English drama has English rich cultural features, to enhance the students understanding of American culture, helps to promote the students to understand the English language and culture, language and culture as well as the expression of cultural connotation is the soul of language, only to master the inner soul of language, to enable students to increase the language knowledge and application skills of identity deep inside, narrow the gap between the students and the English language distance, English professional knowledge is not independent, but depends on various entities form the students to understand the external form of language knowledge, it is the accumulation of learning experience, the cognitive process of English in different physical forms, only to expand their own practical experience, summed up its application ability in multiple contexts, true understanding of English knowledge, only based on their own The structure of knowledge experience background, is the process of deepening understanding, but a mere rote is not really understand, just passive knowledge copy form, copy the contents will be accompanied by the 
passage of time gradually fade, but the real understanding will make the knowledge of English deeply engraved in my mind, for the flexible application of student services the. Drama literature is also a form of artistic expression, teachers guide students to learn the contents of the resolution of drama, tasting in enabling students to receive art, enable students to accumulate basic language skills at the same time, but also promote the students' comprehensive literacy.

\section{The application of Shakespeare's drama in English constructivism teaching mode}

Shakespeare is a famous British dramatist in the half a century of life created in the history of human civilization occupies an important position in the "merchant of Venice", "Romeo and Juliet", "A Midsummer Night's dream" and other great works of drama, to a sense of authenticity, vivid plot by the drama in his dramatic works in the spirit of realism, the four great tragedies is the classic epic drama history, characters, plot and reflection events people through dramatic role in their life, to understand the author's creative thought, Shakespeare drama translation into various languages have been widely spread in the world. The application of Shakespeare drama of English teaching, to enable students to feel the drama, fiction, poetry and other literature will feature comprehensive application form, to enable students to understand the English language and English culture in the context of drama.

English language application ability is a key problem for teachers need to pay attention to in the teaching activities, teachers can be based on the constructivism theory, the classical Shakespeare drama literature, into classroom teaching, so that students can understand more diversified language knowledge, the key to improve the ability of learning English is based on the accumulation of knowledge, teachers can use the "Hamlett" in the classic "To be or not to plays be that, is the question" is introduced into the content of classroom teaching, so that students can understand the repertoire of applied language, such as "the proud man" s contumely "," a sea of troubles "are different in common English collocation form, by explaining the content of teaching, so that students can play in the environment, the application mode of English vocabulary and its different experience The value of language in drama is closer to that in everyday life, and it is different from written language, thus enabling students to enhance their understanding of British social culture through the process of dramatic language learning[5].

Shakespeare drama has strong readability and plot, at the same time, it has strong practicality, teachers can choose proper teaching content, organize students to play from the rehearsal, the appropriate role setting arrangement of dramatic characters, students and teachers in-depth role-playing diagonal needle exchange and discussion, to achieve effective teaching the communication process, for learning and performance of the drama language, to embody the students for the knowledge of English language comprehension and expression ability, application of the unique situation of drama, to enhance students' ability to use language in actual context, interaction performance between students conforms to the constructivism teaching thoughts, collaborative learning is learning coordination the ability, but also the coordination of interpersonal relationship among students, students build a strong language in the process of cooperative learning in each other Language learning atmosphere, so that students can continue to accept the influence of English language environment, change students closed English learning mode, many students will have no real English environment to practice oral English, and drama rehearsal requires some time to prepare students to achieve personal learning ability and application ability in persistent in the learning environment to enhance.

Shakespeare's drama has many classical repertoire, teachers can encourage students to use their spare time to actively carry out the plays of Shakespeare autonomous learning, feelings of literary giants meticulous charm, in the author's pen to vivid plots, the author's writing style and language should be used to improve students' English learning, the accumulation of knowledge, for the application of language the creation of English also have a more intuitive feeling, expand their horizons of knowledge. The drama works with plot and chapters, usually are easy to understand, relatively uncommon words, students' application plays learning autonomy in English reading, can be more smoothly into the process of autonomous learning, compared to other forms of learning, 
but also need to check the information, learning vocabulary, extensive reading is also prone to emotional burnout, imagination the students' learning efficiency and learning enthusiasm, application plays for autonomous learning, to improve their reading and writing will have a huge role in promoting[6].

Constructivism mode need to embody the structured knowledge structure, learning process, teachers' professional application of Shakespeare drama teaching content set, will need their own teaching status into knowledge guide, change the traditional teaching process of English teaching indoctrination, while students from passive recipients of knowledge into active acquisition, focus on learning the process, to guide students to explore the learning demands of its own, a clear focus on their own learning, learning methods suitable for mining itself, and thus can achieve in the learning process to enhance the ability, with good knowledge and lack of oral expression ability of the students, can be applied to teaching practice active listening and speaking training space for their creation. While the professional foundation is relatively poor students through the learning process to strengthen their professional knowledge Cultivate, consolidate the professional learning foundation, and master more English language application knowledge, so that each student can learn in the process of learning, gain, apply knowledge, and promote the teaching goal of English major.

\section{Conclusion}

Not only requires students to master professional knowledge of English learning professional, more flexible application needs to carry out a variety of situations of professional knowledge, the application of social constructivist model focus on students' learning environment and learning process, teachers should change the teaching idea and method of the realization of classroom teaching reform, Shakespeare's drama in English teaching. Teachers can enhance students' learning ability for English language, organize students drama rehearsal activities, encourage students to independent learning, strengthen students' subjective learning identity reflects the construct significance using drama content, realize the organic combination of teaching and practice teaching, application of drama teaching situation to enhance students' understanding and the application of English language ability, to promote the teaching objectives of English Majors Realization。

\section{Acknowledgements}

The moral and ethical analysis of Shakespeare's four tragedies in Tianjin Institute of Commerce University of Hong Kong in 2016 (item number: BD20169105)

\section{References}

[1] Cockin, Mary J. Shakespeare's use of the Christian dimension in four major tragedies, and its dramatic effect on early audiences[J]. 2003.

[2]Paridonsteeman T V, Humanities F O. 'Spoken' English in Dramatic Texts: From You and Thou in William Shakespeare' s The Tempest to a General Model of Everyday Language[J]. 2015.

[3]Valle Martínez S. The Elizabethan Era Nowadays: analysis of the role of women in Shakespeare' s drama from a contemporary perspective[J]. 2014.

[4]Aizhu X U, Han G. Similarities and Differences between Tang Xianzu's and Shakespeare's Dramatic Images from the Perspective of Comparative Study[J]. Journal of Zhejiang Vocational Academy of Art, 2016.

[5]Marcus Nordlund. Theorising Early Modern Jealousy. A Biocultural Perspective on Shakespeare's Othello[J]. Studia Neophilologica, 2002, 74(2):146-160.

[6]Cockin, Mary J. Shakespeare's use of the Christian dimension in four major tragedies, and its 
dramatic effect on early audiences[J]. 2003. 